Jurnal Ilmu Dan Teknologi Kesehatan

Vol 6, No 2, Maret 2019,

ISSN: 2338-9095 (Print)

ISSN: 2338-9109 (online)

\title{
Faktor-Faktor Risiko Terjadinya Berat Bayi Lahir Rendah
}

\author{
Lydia Febrina, Triana Sri Herdjanti, Siti Nikmah \\ Poltekkes Kemenkes Bengkulu \\ Email: lydia.fe15@gmail.com
}

\begin{abstract}
Artikel history
Dikirim, Jan $8^{\text {th }}, 2019$

Ditinjau, Feb $20^{\text {th }}, 2019$

Diterima, Mar $4^{\text {th }}, 2019$
\end{abstract}

\begin{abstract}
Low Birth Weight ( $L B W$ ) is the proportion of live births weighing less than 2,500 grams and 20 times the chance of dying in infancy. $L B W$ is the result of premature birth $(<37$ weeks gestation) or impaired intrauterine growth. Neonatal mortality is one of the indicators determining the health and welfare of children. IMR in Banjarnegara Regency in 2015 was 13.23 per 1,000 live births which in absolute terms still ranked highest in Central Java Province. The formulation of the problem is risk factors of low birth weight at Karang Kobar Health Center in Banjarnegara Regency in 2018. This research is a descriptive analytic study using case control study design. The research sample was taken from the total number of $L B W$ in January to December 2017. Data were analyzed univariate and bivariate. The results of the study, the factors associated with the incidence of $L B W$ are the factors of maternal age during pregnancy, gestational age, anemia, and nutrition pregnant women.
\end{abstract}

Keywords: LBW; age of pregnant women; parity; anemia; nutrition; pre-eclampsia

\begin{abstract}
ABSTRAK
Berat Badan Lahir Rendah (BBLR) adalah proporsi kelahiran hidup dengan berat kurang dari 2.500 gram dan 20 kali kemungkinan meninggal pada masa bayi. BBLR merupakan hasil dari kelahiran prematur (kehamilan $<37$ minggu) atau pertumbuhan intrauterine yang terganggu. Kematian neonatal menjadi salah satu indikator penentu kesehatan dan kesejahteraan anak. AKB di Kabupaten Banjarnegara tahun 2015 yaitu 13.23 per 1.000 kelahiran hidup dimana secara absolut angka tersebut masih menduduki urutan tertinggi di Provinsi Jawa Tengah. Rumusan masalahnya adalah faktor-faktor risiko terjadinya bayi berat lahir rendah di Puskesmas Karang Kobar Kabupaten Banjarnegara tahun 2018. Penelitian ini merupakan penelitian deskriptif analitik menggunakan desain case control study. Sampel penelitian ini diambil dari jumlah keseluruhan BBLR bulan Januari sampai Desember 2017. Data dianalisis secara univariat dan bivariat. Hasil penelitian, faktor-faktor yang berhubungan dengan kejadian BBLR adalah faktor usia ibu saat hamil, usia kehamilan, anemia, dan gizi ibu hamil.
\end{abstract} Kata Kunci: BBLR; usia ibu hamil; paritas; anemia; LiLA; pre-eklamsi 


\section{PENDAHULUAN}

Berat badan saat lahir adalah indikator kesehatan seseorang dan prediktor yang diterima secara global untuk kelangsungan hidup masa kanak-kanak dan meningkatkan berat badan lahir adalah langkah penting dalam memecahkan masalah siklus hidup dari kekurangan gizi.

Menurut World Health Organization (WHO), Berat Badan Lahir Rendah (BBLR) adalah proporsi kelahiran hidup dengan berat kurang dari 2.500 gram dan 20 kali kemungkinan meninggal pada masa bayi. BBLR merupakan hasil dari kelahiran prematur (kehamilan $<37$ minggu) atau pertumbuhan intrauterine yang terganggu (WHO, 2015).

Pemeliharaan kesehatan anak merupakan suatu bentuk upaya guna menciptakan generasi muda masa depan yang sehat, cerdas, kreatif, dan inovatif. Upaya pemeliharaan kesehatan anak yang berkualitas sangat penting bagi kehidupan anak karena diharapkan dapat menurunkan angka kematian anak. Derajat kesehatan suatu negara dapat diukur dari berbagai indikator kesehatan seperti Angka Kematian Neonatal (AKN), Angka Kematian Bayi (AKB), dan Angka Kematian Balita (AKABA). Bayi dan anak menjadi fokus penting karena masih mengalami berbagai ancaman masalah kesehatan selama masa pertumbuhannya yang akan berdampak pada kecacatan atau bahkan kematian (RI, 2017).

Kematian neonatal menjadi salah satu indikator penentu kesehatan dan kesejahteraan anak. Era Millennium Development Goals (MDGs) telah berakhir pada tahun 2015, seluruh negara di dunia termasuk Indonesia menyetujui sebuah kerangka kerja yang baru yaitu The Sustainable Development Goals (SDGs) dimana terdapat salah satu target dan komitmen baru yang disepakati untuk menurunkan angka kematian anak yakni berusaha menurunkan Angka Kematian Neonatal setidaknya hingga 12 per 1.000 kelahiran hidup (Bappenas, 2016).

Secara global, lebih dari 20 juta bayi, mewakili 15,5\% dari semua kelahiran, lahir dengan berat badan lahir rendah; 95,6\% dari mereka tinggal di negara berkembang, terhitung $17 \%$ dari semua kelahiran di negara berkembang. Prevalensi berat lahir rendah adalah $40 \%$, dan usia kehamilan kurang dari 37 minggu, usia ibu kurang dari 20 tahun, pemeriksaan antenatal tidak teratur, tinggi badan ibu kurang dari 150 $\mathrm{cm}$, ibu berat badan kurang dari $50 \mathrm{~kg}$, hemoglobin kurang dari $10 \mathrm{gm} / \mathrm{dl}$, dan kerja fisik yang berat merupakan faktor penentu berat lahir rendah (Sebayang et al., 2012).

Angka Kematian Bayi (AKB) dan Angka Kematian Neonatal (AKN) di Indonesia tergolong tinggi dibanding dengan 
beberapa negara serumpun Asia Tenggara lainnya. AKB di Indonesia pada tahun 2015 sebesar 22,8 per 1000 kelahiran hidup dan AKN 13,5 per 1000 kelahiran hidup, Malaysia AKB sebesar 6 per 1000 kelahiran hidup dan AKN 3,9 per 1000 kelahiran hidup, Filipina dengan AKB 22,2 per 1000 kelahiran hidup dan AKN 12,6 per 1000 kelahiran hidup, Singapura yang memiliki tingkat $\mathrm{AKB}$ terendah hanya sebesar 2,1 per 1000 kelahiran hidup dan AKN sebesar 1 per 1000 kelahiran hidup (Wang et al., 2015).

Profil Kesehatan Provinsi Jawa Tengah Tahun 2016 BBLR merupakan salah satu faktor risiko kematian bayi. Oleh karena itu sebagai salah satu upaya untuk mencegah terjadinya kematian bayi adalah penanganan BBLR. BBLR adalah bayi yang lahir dengan berat badan kurang dari 2500 gram. Penyebab terjadinya BBLR antara lain karena ibu hamil mengalami anemia, kurang asupan gizi waktu dalam kandungan, ataupun lahir kurang bulan. Bayi yang lahir dengan berat badan rendah perlu penanganan yang serius, karena pada kondisi tersebut bayi mudah sekali mengalami hipotermi dan belum sempurnanya pembentukan organ-organ tubuhnya yang biasanya akan menjadi penyebab utama kematian bayi ('Profil Kesehatan Propinsi Jawa Tengah Tahun 2016', 2016).
Angka Kematian Bayi di Kabupaten Banjarnegara pada tahun 2015 yaitu 13.23 per 1.000 kelahiran hidup dimana secara absolut dihitung dari jumlah kematian bayi sebesar 209 dengan kelahiran hidup sebesar 15.798. Angka tersebut masih menduduki urutan tertinggi di Provinsi Jawa Tengah. Masih tingginya Angka Kematian Bayi (AKB) disebabkan oleh banyak faktor antara lain tingginya kasus kelahiran preterm (BBLR), keterlambatan deteksi ditingkat masyarakat, keterbatasan fasilitas yang tersedia terutama pelayanan rujukan, keterbatasan kemampuan petugas dalam melakukan deteksi risiko, keterbatasan kompetensi, kepatuhan petugas terhadap SOP belum maksimal, serta adanya faktor lain dari kondisi ibu terutama status gizi (KEK, Anemia dan Penyakit Kronis) (Banjarnegara, 2015).

Faktor yang memengaruhi kejadian BBLR sebuah survei epidemiologi dari Cina menunjukkan bahwa berat badan lahir rendah dikaitkan dengan usia ibu kurang dari 20 tahun, tingkat pendidikan ibu yang rendah, riwayat kehamilan buruk sebelumnya, dan morbiditas kehamilan dan komplikasi, seperti gangguan hipertensi selama kehamilan, anemia, oligohidramnion, ketuban pecah dini, dan diabetes kehamilan. Dalam sebuah studi dari Lombok, Indonesia, faktor penentu BBLR termasuk jenis kelamin bayi, pendidikan wanita, musim saat lahir, 
tempat tinggal ibu, tingkat ekonomi, lingkar lengan atas ibu, tinggi badan ibu, urutan kelahiran, dan jarak kehamilan (Sebayang et al., 2012).

Dalam penelitian ini, peneliti menggunakan data rekam medik (RM) berupa buku KIA dan kohort untuk melihat faktor-faktor yang menyebabkan kejadian BBLR berdasarkan berat lahir dari faktor ibu dan janin sehingga dapat dilakukan tindak lanjut guna meminimalkan terjadinya BBLR. Tujuan dari penelitian ini adalah untuk mengetahui faktor-faktor yang berpengaruh terhadap kejadian BBLR di Puskesmas Karang Kobar wilayah kerja Dinas Kesehatan Kabupaten Banjarnegara.

\section{METODE}

Penelitian ini merupakan penelitian deskriptif analitik yaitu suatu penelitian dengan mendeskripsikan bagaimana faktor risiko yang berhubungan dengan kejadian BBLR. Dilakukan analisis mengenai adanya korelasi antara fenomena yaktu antara faktor risiko dengan faktor efek. Penelitian ini menggunakan desain case control study, dimana ada kelompok kasus dan kelompok kontrol penelitian yang dilakukan di wilayah kerja Puskesmas Karang Kobar Kabupaten Banjarnegara.

Metode pengumpulan data pada penelitian ini menggunakan data sekunder dari register kohort ibu dan anak untuk melihat apakah umur ibu, paritas, usia kehamilan, anemia, status gizi (LLA), dan pre-eklamsi merupakan faktor risiko terjadinya BBLR. Populasi penelitian ini adalah seluruh jumlah bayi yang lahir dengan BBLR di Puskesmas Karang Kobar Kabupaten Banjarnegara yang ada pada pendataan bulan Januari sampai Desember 2017 berjumlah 32 bayi. Sedangkan untuk kontrol digunakan ibu-ibu yang mempunyai bayi dengan berat badan lahir normal yang berjumlah 32 orang, sehingga perbandingan antara kelompok kasus dan kelompok kontrol adalah 1:1.

Penelitian ini akan dilakukan di Puskesmas Karang Kobar wilayah Kerja Dinas Kesehatan Kabupaten Banjarnegara selama 10 hari dari tanggal 24 Juli - 03 Agustus 2018.

Teknik pengumpulan data menggunakan data sekunder yang diperoleh dari buku KIA dan register kohort Kesehatan Ibu dan Anak. Alat yang digunakan dalam penelitian dengan menggunakan checklist. Sebagai variable independen adalah usia ibu, paritas, umur kehamilan, anemia, gizi ibu saat hamil, dan pre-eklamsia. Sedangkan sebagai variable dependen adalah bayi BBLR.

Analisis data univariat yaitu analisis yang digunakan terhadap tiap variabel hasil penelitian yang hanya menghasilkan distribusi dan persentase tiap variabel (Notoatmojo, 2010). Selain itu untuk mengetahui kemaknaan hubungan antara 
variabel independen dan dependen maka uji statistik yang digunakan adalah chi-square dengan derajat kepercayaan 95\% $(\alpha=5 \%)$. Bila p-value $<0.05$ maka uji statistic bermakna (signifikan), jika p-value $>0.0$ maka perhitungan statistik tidak bermakna.

\section{HASIL DAN PEMBAHASAN}

Penelitian ini dilakukan pada 32 responden yang memiliki berat badan bayi lahir $<2.500$ gram dipilih untuk kelompok kasus dan kelompok kontrol 32 responden dengan berat badan bayi lahir $>2.500$ gram. Hasil analisis deskriptif adalah untuk melihat distribusi antara masing-masing faktor risiko dan hasil analisis bivariat adalah faktor risiko terjadinya berat badan lahir rendah.

Usia terendah ibu waktu hamil pada kelompok kasus adalah 16 tahun 1 orang (3.1\%) dan usia ibu tertinggi 42 tahun 1 orang (3.1\%). Rata-rata usia ibu saat hamil pada kelompok kasus 24 tahun. Usia terbanyak 17 tahun yaitu berjumlah 5 responden (15.6\%). Usia terendah ibu pada saat hamil pada kelompok kontrol adalah 17 tahun berjumlah 5 orang $(15.6 \%)$ dan usia tertinggi 38 tahun 1 orang (3.1\%). Rata-rata usia ibu pada saat hamil pada kelompok kontrol adalah 24 tahun. Usia terbanyak adalah 17 tahun 5 responden (15.6\%). Berdasarkan hasil uji statistik ada hubungan antara usia ibu saat hamil dengan kejadian BBLR.

Banyak studi epidemiologi mencatat bahwa kejadian BBLR meningkat pada risiko tinggi usia reproduksi yaitu $<20$ tahun dan $>35$ tahun. Pada kehamilan remaja yang menyebabkannya adalah tingkat ekonomi rendah, perawatan antenatal yang tidak memadai, dan berat ibu lebih rendah. Sedangkan di usia lebih tua memiliki insiden komplikasi kehamilan yang tinggi, misalnya hipertensi dan diabetes serta peningkatan gangguan arteriosklerotik vaskular pada tingkat myometrium (Goisis et al., 2017).

Tabel 1. Pengaruh usia ibu pada saat hamil terhadap BBLR

\begin{tabular}{|c|c|c|c|c|c|c|}
\hline \multirow[t]{3}{*}{ Usia Ibu } & \multicolumn{4}{|c|}{ Kejadian BBLR } & \multirow{3}{*}{ OR } & \multirow{3}{*}{$P$ value } \\
\hline & \multicolumn{2}{|c|}{ Kasus } & \multicolumn{2}{|c|}{ Kontrol } & & \\
\hline & $f$ & $\%$ & $\mathrm{~F}$ & $\%$ & & \\
\hline Berisiko & 20 & 62.5 & 6 & 18.8 & 7.222 & 0.000 \\
\hline Tidak Berisiko & 12 & 37.5 & 26 & 81.2 & $\begin{array}{l}2.309- \\
22.588\end{array}$ & \\
\hline Jumlah & 32 & 100 & 32 & 100 & & \\
\hline
\end{tabular}


Berdasarkan tabel 1, dapat diketahui proporsi umur ibu saat hamil yang berisiko pada kelompok kasus lebih besar (62.5\%) dibanding dengan proporsi usia ibu yang berisiko pada kelompok kontrol (18.8\%). Hasil uji statistik dengan menggunakan uji chi-square ada hubungan bermakna antara umur ibu saat hamil dengan kejadian BBLR $(\mathrm{p}=0.000)$ dengan nilai $\mathrm{OR}=7.222$.

Hasil penelitian menemukan pengaruh usia berisiko dengan kejadian BBLR dengan nilai OR sebesar 7.222, artinya ibu hamil dengan usia $<20$ dan $>35$ tahun memiliki risiko 7.222 kali untuk melahirkan bayi BBLR dibanding dengan usia ibu saat hamil 20-35 tahun (usia reproduksi sehat).

Anak-anak dari ibu yang berusia lebih muda memiliki $20-30 \%$ peningkatan risiko BBLR dan kelahiran prematur serta 30$40 \%$ risiko pengerdilan 2 tahun (stunting), dikarenakan tidak hanya otonomi dalam perilaku ibu sehari-hari (Fall et al., 2015).

Tabel 2. Pengaruh paritas terhadap BBLR

\begin{tabular}{|c|c|c|c|c|c|c|}
\hline \multirow[t]{3}{*}{ Paritas Ibu } & \multicolumn{4}{|c|}{ Kejadian BBLR } & \multirow{3}{*}{$\begin{array}{c}\text { OR } \\
(95 \% \text { CI })\end{array}$} & \multirow{3}{*}{$P$ value } \\
\hline & \multicolumn{2}{|c|}{ Kasus } & \multicolumn{2}{|c|}{ Kontrol } & & \\
\hline & $\mathrm{f}$ & $\%$ & $\mathrm{~F}$ & $\%$ & & \\
\hline Tidak Berisiko & 16 & 50 & 16 & 50 & 1.000 & 1.000 \\
\hline Berisiko & 16 & 50 & 16 & 50 & & \\
\hline Jumlah & 32 & 100 & 32 & 100 & & \\
\hline
\end{tabular}

Dilihat dari tabel 2, persentase paritas ibu yang berisiko pada kelompok kasus sama besar $(50 \%)$ dengan persentase paritas ibu yang berisiko pada kelompok kontrol
(50\%). Hasil uji statistik dengan menggunakan uji chi-square tidak ada hubungan bermakna antara umur ibu saat hamil dengan kejadian BBLR $(\mathrm{p}=1.000)$.

Tabel 3. Pengaruh usia kehamilan terhadap BBLR

\begin{tabular}{lcccccc}
\hline \multirow{2}{*}{ Usia Hamil } & \multicolumn{4}{c}{ Kejadian BBLR } & \multirow{2}{*}{ OR } & \multirow{2}{*}{ P value } \\
\cline { 2 - 5 } & \multicolumn{3}{c}{ Kasus } & \multicolumn{2}{c}{ Kontrol } & \\
\cline { 2 - 5 } & $\mathrm{f}$ & $\%$ & $\mathrm{~F}$ & $\%$ & & \\
\hline Aterm & 13 & 40.6 & 31 & 96.9 & 14.091 & 0.000 \\
\hline Prematur & 19 & 59.4 & 1 & 3.1 & $2.066-16.103$ & \\
\cline { 1 - 4 } & & & & & & \\
\hline Jumlah & 32 & 100 & 32 & 100 & & \\
\hline
\end{tabular}

Pada tabel 3 didapatkan hasil persentase usia kehamilan prematur pada kelompok kasus lebih besar (59.4\%) dibandingkan dengan persentase usia kehamilan prematur pada kelompok kontrol (3.1\%). Hasil uji statistik dengan menggunakan uji chi- 
square ada hubungan bermakna antara usia kehamilan aterm saat hamil dengan kejadian BBLR $(\mathrm{p}=0.000)$ dengan nilai $\mathrm{OR}=14.091$.

Hasil penelitian menemukan pengaruh LiLA berisiko dengan kejadian BBLR dengan nilai OR sebesar 2.431, artinya ibu hamil dengan LiLA $<23.5 \mathrm{~cm}$ memiliki risiko 2.431 kali untuk melahirkan bayi BBLR dibanding dengan LiLA $>23.5 \mathrm{~cm}$ (normal).

Hasil penelitian ini diperoleh nilai OR 14.091 (95\% CI 2.066-16.103), pada CI 95\% antara lower dan upper limit tidak terdapat nilai 1, sehingga nilai OR bermakna atau dapat disimpulkan umur kehamilan $<37$ minggu mempunyai risiko 14.091 kali melahirkan bayi BBLR dibandingkan dengan ibu yang melahirkan pada usia kehamilan $>37$ minggu atau aterm di Puskesmas Karang Kobar Kabupaten Banjarnegara tahun 2017. Hal ini dimungkinkan terjadi karena umur kehamilan yang berisiko sangat tinggi pada ibu yang melahirkan BBLR lebih besar (59.4\%) dibanding dengan ibu yang melahirkan bayi berat lahir normal (3.1\%). Tingginya risiko umur kehamilan terhadap BBLR pada penelitian ini disebabkan karena secara biologis berat badan bayi akan bertambah sesuai dengan usia kehamilan.

Tabel 4. Pengaruh kadar $\mathrm{Hb}$ terhadap BBLR

\begin{tabular}{|c|c|c|c|c|c|c|}
\hline \multirow[t]{3}{*}{$\mathbf{H b}$} & \multicolumn{4}{|c|}{ Kejadian BBLR } & \multirow{3}{*}{$\begin{array}{c}\text { OR } \\
(95 \% \mathrm{CI})\end{array}$} & \multirow{3}{*}{ P value } \\
\hline & \multicolumn{2}{|c|}{ Kasus } & \multicolumn{2}{|c|}{ Kontrol } & & \\
\hline & $\mathrm{F}$ & $\%$ & $\mathrm{~F}$ & $\%$ & & \\
\hline$>11 \mathrm{gr} \%$ & 9 & 28.1 & 23 & 71.9 & 2.806 & 0.000 \\
\hline$<11$ gr $\%$ & 23 & 71.9 & 9 & 28.1 & $1.410-4.632$ & \\
\hline Jumlah & 32 & 100 & 32 & 100 & & \\
\hline
\end{tabular}

Berdasarkan tabel 4, didapatkan hasil persentase anemia ibu saat hamil pada kelompok kasus lebih besar (71.9\%) dibandingkan dengan persentase anemia ibu saat hamil pada kelompok kontrol (28.1\%). Hasil uji statistik dengan menggunakan uji chi-square ada hubungan bermakna antara usia kehamilan aterm saat hamil dengan kejadian BBLR $(p=0.000)$ dengan nilai $\mathrm{OR}=2.806$.

Hasil analisis bivariat hubungan antara kadar haemoglobine <11 gr/dl dengan kejadian BBLR ada hubungan yang bermakna, artinya ada hubungan antara anemia pada ibu hamil dengan kejadian BBLR. Hasil yang bermakna dikarenakan ibu hamil dengan anemia lebih banyak 
terjadi pada kelompok kasus berjumlah 23 orang (71.9\%) dibandingkan dengan kelompok kontrol 9 orang (28.1\%). Risiko kejadian BBLR hasil penelitian ini 2.806 kali lebih besar terjadi pada ibu yang anemia daripada ibu yang tidak anemia.

Pada kehamilan normal, konsentrasi haemoglobine ibu menurun dalam 20 minggu pertama kehamilan, tetap konstan hingga minggu ke-30 dan kemudian meningkat sedikit.

Kejadian anemia meningkat seiring dengan bertambahnya umur kehamilan. pada saat kehamilan ibu mengalami perubahan fisiologis dimana terjadi ketidakseimbangan jumlah plasma darah dan sel darah merah. Ketidakseimbangan ini dapat dilihat dalam bentuk penurunan kadar haemoglobine terutama pada kehamilan trimester II, sehingga saat itu ibu hamil membutuhkan zat besi untuk pertumbuhan perkembangan kehamilan (Purwanto and Wahyuni, 2017).

Beberapa peneliti telah mengamati bahwa $\mathrm{Hb}<9$ gr/dl selama kehamilan dihubungkan dengan peningkatan risiko BBLR dan prematuritas (Ahankari et al., 2017). Hasil penelitian ini sejalan dengan Ahankari (2017), bahwa nilai $\mathrm{Hb}$ antara 9.5 - 10.5 gr/dl merupakan penyebab peningkatan insidensi BBLR, sebaliknya peningkatan nilai $\mathrm{Hb}>12 \mathrm{gr} / \mathrm{dl}$ menurunkan insidensi prematuritas dan BBLR.

Tabel 5. Pengaruh Status Gizi Ibu (LiLA) terhadap BBLR

\begin{tabular}{lcccccc}
\hline \multirow{2}{*}{ LiLA } & \multicolumn{4}{c}{ Kejadian BBLR } & \multirow{2}{*}{ OR } & \multirow{2}{*}{ P value } \\
\cline { 2 - 5 } & \multicolumn{2}{c}{ Kasus } & \multicolumn{2}{c}{ Kontrol } & \\
\cline { 2 - 5 } & $\mathrm{f}$ & $\%$ & $\mathrm{F5} \% \mathbf{C I})$ & \\
\hline$>\mathbf{2 3 . 5} \mathbf{~ c m}$ & 15 & 46.9 & 26 & 81.3 & 2.431 & 0.004 \\
\hline$<\mathbf{2 3 . 5} \mathbf{~ c m}$ & 17 & 53.1 & 6 & 18.7 & $1.176-5.125$ & \\
& & & & & & \\
\hline Jumlah & 32 & 100 & 32 & 100 & & \\
\hline
\end{tabular}

Berdasarkan tabel 5, persentase LiLA $<23.5 \mathrm{~cm}$ pada kelompok kasus lebih besar (53.1\%) dibandingkan dengan persentase LiLA $<23.5 \mathrm{~cm}$ pada kelompok kontrol (18.8\%). Hasil uji statistik dengan menggunakan uji chi-square ada hubungan bermakna antara usia kehamilan prematur saat hamil dengan kejadian BBLR ( $\mathrm{p}=$ 0.004 ) dengan nilai $\mathrm{OR}=2.431$.

Dari hasil penelitian, pada tabel 5, persentase ukuran LiLA $<23.5 \mathrm{~cm}$ pada kejadian BBLR yaitu 53.1\%. Hal ini dapat dijelaskan, bahwa masih ada ibu yang memiliki status gizi kurang pada saat hamil dilihat dari ukuran LiLA. 
Seperti yang diungkapkan oleh Satriono (2010) bahwa antropometri yang paling sering digunakan untuk menilai status gizi yaitu LiLA merupakan salah satu cara untuk mengetahui risiko Kekurangan Energi Kronis (KEK) Wanita Usia Subur (WUS). Penilaian yang lebih baik untuk menilai status gizi ibu hamil yaitu dengan pengukuran LiLA, karena pada wanita hamil dengan malnutrisi (gizi kurang atau lebih). Di Indonesia batas ambang LiLA dengan risiko KEK adalah $23.5 \mathrm{~cm}$, artinya ibu hamil dengan risiko KEK diperkirakan akan melahirkan bayi BBLR yang berisiko kematian, gizi kurang, serta gangguan pertumbuhan dan gangguan perkembangan anak. Pada penelitian ini juga berhubungan dengan usia ibu $<20$ tahun dan LiLA juga $<23.5 \mathrm{~cm}$, dimana beberapa organ reproduksi dan fisik yang belum cukup berkembang.

Berat bayi yang dilahirkan dapat dipengaruhi oleh status gizi ibu baik sebelum hamil maupun saat hamil. Status gizi ibu yang kurang sebelum hamil mempunyai risiko 4.27 kali untuk melahirkan bayi BBLR dibandingkan dengan ibu yang mempunyai status gizi baik (Kusparlina, 2016).

Tabel 6. Pengaruh pre-eklamsi terhadap BBLR

\begin{tabular}{|c|c|c|c|c|c|c|}
\hline \multirow[t]{3}{*}{ Pre-eklamsi } & \multicolumn{4}{|c|}{ Kejadian BBLR } & \multirow{3}{*}{$\begin{array}{c}\text { OR } \\
(95 \% \mathrm{CI})\end{array}$} & \multirow{3}{*}{$P$ value } \\
\hline & \multicolumn{2}{|c|}{ Kasus } & \multicolumn{2}{|c|}{ Kontrol } & & \\
\hline & $\mathrm{F}$ & $\%$ & $\mathrm{~F}$ & $\%$ & & \\
\hline Tidak & 25 & 78.1 & 24 & 75 & 1.190 & 0.768 \\
\hline Pre-eklamsi & 7 & 21.9 & 8 & 25 & $0.374-3.793$ & \\
\hline Jumlah & 32 & 100 & 32 & 100 & & \\
\hline
\end{tabular}

Pada tabel 6, dapat dilihat persentase preeklamsi pada kelompok kasus lebih kecil (21.9\%) dibandingkan dengan persentase pre-eklamsi pada kelompok kontrol (25\%). Hasil uji statistik dengan menggunakan uji chi-square tidak ada hubungan bermakna antara pre-eklamsi dengan kejadian BBLR $(\mathrm{p}=0.768)$.

Insiden dan faktor risiko BBLR dalam penelitian ini sesuai dengan penelitian lain.
Usia ibu saat hamil, usia kehamilan, anemia ibu, LiLA $<23.5 \mathrm{~cm}$ adalah faktor risiko yang signifikan untuk BBLR. Berat lahir rendah dikaitkan dengan kematian dan morbiditas perinatal. Hasil penelitian ini memberikan informasi penting pada tenaga kesehatan, ibu hamil yang akan dipertimbangkan selama perawatan dan konseling ibu hamil dengan faktor risiko untuk BBLR, juga ibu dengan bayi BBLR 
untuk mencegah morbiditas dan mortalitas perinatal.

Ibu hamil dengan LiLA $<23.5 \mathrm{~cm}$ cenderung mengalami Kekurangan Energi Kronis (KEK), artinya ibu sudah mengalami keadaan kurang gizi dalam jangka waktu yang lama, maka kebutuhan nutrisi untuk proses pertumbuhan dan perkembangan janin menjadi terhambat, sehingga berat badan bayi lahir rendah. Kekurangan energi kronis menyebabkan ibu hamil tidak mempunyai cadangan zat gizi yang adekuat untuk menyediakan kebutuhan fisiologi kehamilan yaitu perubahan hormon dan peningkatan volume darah untuk mensuplai oksigen keseluruh sistem untuk pertumbuhan janin.

\section{SIMPULAN}

Faktor-faktor yang berhubungan dengan kejadian BBLR adalah faktor usia ibu saat hamil, usia kehamilan, anemia, dan LiLA $<23.5 \mathrm{~cm}$. Hasil dari penelitian tersebut menunjukkan bahwa persentase umur ibu saat hamil yang berisiko pada kelompok kasus lebih besar (62.5\%) dengan hasil uji statistik ada hubungan bermakna antara umur ibu saat hamil dengan kejadian $\operatorname{BBLR}(\mathrm{p}=0.000)$ dengan nilai $\mathrm{OR}=$ 7.222, persentase paritas ibu yang berisiko pada kelompok kasus (50\%) dengan hasil uji statistik tidak ada hubungan bermakna antara umur ibu saat hamil dengan kejadian BBLR $(\mathrm{p}=1.000)$, persentase usia kehamilan prematur pada kelompok kasus (59.4\%) dengan hasil uji statistik ada hubungan bermakna antara usia kehamilan aterm saat hamil dengan kejadian BBLR $(\mathrm{p}=0.000)$ dengan nilai $\mathrm{OR}=14.091$, persentase anemia ibu saat hamil pada kelompok kasus (71.9\%) dengan hasil uji statistik ada hubungan bermakna antara usia kehamilan aterm saat hamil dengan kejadian BBLR $(\mathrm{p}=0.000)$ dengan nilai $\mathrm{OR}=2.806$, persentase status gizi ibu hamil (LiLA $<23.5 \mathrm{~cm}$ ) pada kelompok kasus (53.1\%) dengan hasil uji statistik ada hubungan bermakna antara usia kehamilan prematur saat hamil dengan kejadian BBLR $(\mathrm{p}=0.004)$ dengan nilai $\mathrm{OR}=2.431$, dan persentase pre-eklamsi pada kelompok kasus (21.9\%) dengan hasil uji statistik tidak ada hubungan bermakna antara pre-eklamsi dengan kejadian BBLR $(\mathrm{p}=0.768)$.

Bagi Puskesmas diharapkan mengaktifkan peran serta masyarakat dan tokoh masyarakat dalam mendukung program kesehatan ibu dan anak ini secara berkesinambungan dengan tetap memberikan pembinaan agar terbentuk perilaku yang baik dari masyarakat dalam pemanfaatan fasilitas kesehatan serta peningkatan kualitas pelayanan dengan cara memberikan pelayanan antenatal terintegrasi sesuai dengan standar minimal, melakukan KIE (Komunikasi, Informasi, Edukasi) pada semua ibu hamil dan 
keluarga. Bagi masyarakat diharapkan peran serta keluarga dan masyarakat dalam memotivasi ibu hamil untuk melakukan pemeriksaan kehamilan yang adekuat dan mengubah pola hidup yang sehat. Bagi peneliti lain hendaknya lebih banyak penelitian yang harus dilakukan pada penyebab dan pencegahan faktor-faktor risiko yang terkait dengan BBLR.

\section{DAFTAR RUJUKAN}

Ahankari, A. S. et al. 2017. 'Risk factors for maternal anaemia and low birth weight in pregnant women living in rural India: a prospective cohort study', Public Health. Elsevier Ltd, 151, pp. 63-73. doi: 10.1016/j.puhe.2017.06.023.

Banjarnegara. 2015. 'Porfil Kesehatan Tahun $2015 \quad$ Kabupaten Banjarnegara'.

Fall, C. H. D. et al. 2015 'Association between maternal age at childbirth and child and adult outcomes in the off spring: a prospective study in fi ve low-income and middle-income countries (COHORTS collaboration )', The Lancet Global Health. Fall et al. Open access article published under the terms of $\mathrm{CC} \mathrm{BY,3(7),} \mathrm{pp.}$ e366-e377. doi: 10.1016/S2214109X(15)00038-8.

Goisis, A. et al. 2017 'Original Contribution Advanced Maternal Age and the Risk of Low Birth Weight and Preterm Delivery: a Within-Family Analysis Using Finnish Population
Registers', 186(11), pp. 1219-1226. doi: 10.1093/aje/kwx177.

Kusparlina, E. P. 2016 'Hubungan Antara Umur dan Status Gizi Ibu Berdasarkan Ukuran Lingkar Lengan Atas dengan Jenis BBLR', Jurnal Penelitian Kesehatan Suara Forikes, VII, pp. 21-26.

'Profil Kesehatan Propinsi Jawa Tengah Tahun 2016' 2016. Dinas Kesehatan.

Purwanto, A. D. and Wahyuni, C. U. 2017. 'Hubungan antara Umur Kehamilan, Kehamilan Ganda, Hipertensi, dan Anemia dengan Kejadian Bayi Berat Lahir Rendah (BBLR), Jurnal Berkala Epidemiologi, 4(March 2016), pp. 349-359. doi: 10.20473/jbe.v4i3.

RI, K. 2017. Profil Kesehatan Indonesia, Kemenkes RI. Jakarta.

Sebayang, S. K. et al. 2012. 'Determinants of Low Birthweight, Small-forGestational-Age and Preterm Birth in Lombok, Indonesia: Analyses of the Birthweight Cohort of the Summit Trial', Tropical Medicine \& International Health, 17(8), pp. 938950.

Wang, Y. et al. 2015. 'Folic Acid Supplementation and Dietary Folate Intake, and Risk of Preeclampsia', European Journal of Clinical Nutrition, 69(10), pp. 1145-1150.

WHO 2015 . Neonatal Mortality Rate (Per 1000 Live Births) (Mortality and Global Health Estimates)', World Health Organization. 